\title{
Article
}

\section{'Contemporary Meaning' in Treaty Interpretation in the WTO and ICJ Cases}

Yang $\mathrm{Yu}^{*}$

Treaty interpretation is one of the most crucial roles of international dispute settlement bodies. They can decide the case in the most reasonable way by legally justified interpretation of treaty. In some cases of the WTO and the ICJ, there exist certain types of facts which closely relate to the evolution of the meaning of a term. This research compares the four ICJ cases to the two WTO cases in order to ascertain both similarities and dissimilarities of those cases. Significant is the dissimilarities concerning the related principle on the economic or environmental aspect enshrined in certain agreement. In the context of the WTO dispute settlement, the contemporary meaning could only be adoptable after adequately justifying treaty interpretation by means of the two-step semantic generic-related interpretative approach. Without the second step of principle-related analysis, problems may arise especially from the economic perspective.

Keywords: WTO, ICJ, Treaty Interpretation, Contemporary Meaning, Generic

\section{INTRODUCTION}

Treaty interpretation is one of the most crucial roles for international dispute settlement bodies. They can decide the case in the most reasonable way by legally

\footnotetext{
* Associate Professor at Shanghai University of International Business and Economics School of WTO Research and Education; Research Fellow in Shanghai Center for Global Trade and Economic Governance. Ph.D. (Fudan). This paper is supported by the Shanghai 085 Project of Higher Education Connotation Construction, Shanghai Center for Global Trade and Economic Governance \& China's Economic Forum(SC-GTEG) and the WTO chairs program. Special gratitude extends to Professor Dr. Josef Drexl, Managing Director of Max Planck Institute for Innovation and Competition. The research as a visiting scholar in the Institute facilitated the completion of this article. http://orcid.org/0000-0001-5467-6397 The author may be contacted at: wtoyuyang@suibe.edu.cn
} 
justified interpretation of treaty.

Treaty may not be always interpreted in accordance with an original meaning. International dispute settlement bodies should sometimes consider the evolution of specific terms in order to interpret them fairly and correctly. A noticeable example is the "exhaustible natural resources" in the case of United States - Import Prohibition of Certain Shrimp and Shrimp Products ${ }^{1}$ in which the Appellate Body finally adopted the contemporary meaning of this phrase.

Terms in a treaty would have different connotations following the circumstances. When the meaning of a treaty term is presumed to be evolving, the one has to decide whether to adopt the contemporary or original meaning. There are such cases in the WTO dispute settlement body and the ICJ where contemporary usage of some terms supplanted their original meanings. ${ }^{2}$ A few questions arise in such cases: Is there any possibility to analyze the conventional legal interpretation from a different perspective?; Should the contemporary meaning always be legally adopted in all related cases?; and Will liberal interpretation be criticized as 'judicial activism'?

The primary purpose of this paper is to answer these questions by analyzing several WTO and ICJ cases. This paper is composed of six parts including an introduction and conclusion. Part two will briefly summarize existing cases that addressed interpreting treaty terms based on their contemporary meaning. Part three will comprehensively analyze four ICJ cases in which the Court adopted the 'contemporary' meaning of certain terms. Part four will examine two cases that decided whether to adopt the contemporary meaning of certain words, particularly the contrast with two of the ICJ cases. This part is also to compare the dispute settlement mechanism between the WTO dispute settlement body and the ICJ regarding the legal application of the contemporary meaning of certain terminologies. Part IV will be devoted to discussing the jurisprudential meaning of treaty terms.

\section{Brief Overview: Six Cases Discussing 'Contemporary Meaning"}

\section{A. The ICJ cases}

The four ICJ cases have discussed the 'contemporary meaning.' They may be 
divided into two groups in terms of interpretation and analytical mode. The first group of cases are Aegean Sea Continental Shelf (Greece v. Turkey) ${ }^{5}$ and the Dispute Regarding Navigational and Related Rights (Costa Rica v. Nicaragua). In these cases, the contemporary meaning of the terms were adopted by means of "semantic generic-related analytical mode." The second group of cases are Rights of Nations of the United States of America in Morocco (France V. U.S.) ${ }^{7}$ and Kasikili/Sedudu Island (Botswana/Namibia). ${ }^{8}$ In one of these cases, the contemporary meaning was not adopted; in the other, the semantic generic-related analytical mode was not applied to the interpretations.

In addition to the four cases, there is an Advisory Opinion which also contains some clarifications regarding "the subsequent development of law." Although this clarification is not an official ICJ decision, the similar wording should be noteworthy. In addition, with respect to the terms clarified, the Advisory Opinion could be regarded as the first 'legal precedent' of the aforementioned two cases in which contemporary meanings were adopted. This opinion states that:

\footnotetext{
the concepts...were not static, but were by definition evolutionary....The parties to the Covenant must consequently be deemed to have accepted them as such. That is why, viewing the institutions of 1919 , the Court must take into consideration the changes which have occurred in the supervening half-century, and its interpretation cannot remain unaffected by the subsequent development of law.... Moreover, an international instrument has to be interpreted and applied within the framework of the entire legal system prevailing at the time of the interpretation. $^{10}$
}

The core part of the related interpretation is listed herein in contrast with the analyses of the first two cases of the WTO below. In essence, although the specific expression does not contain the most crucial keyword - 'generic,'- the inherent orientation of legal value is similar, i.e., the contemporary meaning which embodies related evolutionary elements should be predominant.

\section{B. The WTO cases}

The WTO has referred to the 'contemporary meaning' in two cases. One is the United States - Import Prohibition of Certain Shrimp and Shrimp Products, the other, China - Measures Affecting Trading Rights and Distribution Services for 
Certain Publications and Audiovisual Entertainment Products. ${ }^{11}$ It is noteworthy that the Appellate Body, in the second case, directly cited the Dispute regarding Navigational and Related Rights case of the ICJ to justify and fortify its adjudication. $^{12}$

\section{The Four ICJ CASES}

\section{A. Aegean Sea Continental Shelf (Greece v. Turkey)}

\section{Background}

This case was instituted by the Hellenic Republic against the Republic of Turkey concerning the delimitation of the continental shelf appertaining to Greece and Turkey in the Aegean Sea. ${ }^{13}$ The Government of Greece requested the ICJ to adjudge in its favor on six issues. Greece maintained that it was "entitled to exercise over its continental shelf sovereign and exclusive rights for the purpose of researching and exploring it and exploiting its natural resources." ${ }^{14}$ To resolve the dispute, it was crucial to objectively and fairly interpret some key terms such as 'territorial status.'

2. The inherent interpretative logic in treaty interpretation: contemporary usage $v$. original meaning

As to the interpretation of 'territorial status,' one of the most noticeable aspects is the keyword, 'generic.' The ICJ referred to 'generic' eight times in its judgment, so as to illustrate the evolutionary attribute of this term and reinforce the justification of such interpretation. ${ }^{15}$ The repeated references of this keyword outlined the interpretative approach to justify the 'contemporary meaning' of the term. Moreover, the keyword - 'generic' also appeared in the related treaty interpretations in the subsequent cases of Costa Rica v. Nicaragua in the ICJ and the two cases in the WTO, as will be subsequently discussed in this paper. ${ }^{16}$ Consequently, it is necessary to clarify the inherent meaning of the word, 'generic' in this context of treaty interpretation.

The ICJ argues: "This change in the presentation of the first and second reservations only served to emphasize both the generic and the autonomous character of Greece's reservation of disputes relating to its "territorial status.", ${ }^{17}$ Then, it 
directly alleges: “ $\ldots$ in the opinion of the Court, the historical evidence adduced by Greece ... seems rather to confirm that the expression 'territorial status' was used in its ordinary, generic sense...." ${ }^{18}$ Subsequently, the ICJ adjudicates:

in the view of the Court, the term 'territorial status' in the treaty practice of the time did not have the very specific meaning attributed to it by the Greek Government. As the nature of the word 'status' itself indicates, it was a generic term which in the practice of the time was understood as embracing the integrity and frontiers, as well as the legal régime, of the territory in question. ${ }^{19}$

The expression in this paragraph is even clearer. For the sake of more clarity, the ICJ used not only the keyword, 'generic,' but also its antonym, 'specific' to stress the generic attribute of the interpreted term. The ICJ further links 'generic' with 'evolution (evolve)' by stating:

Once it is established that the expression 'the territorial status of Greece' was used in Greece's instrument of accession as a generic term denoting any matters comprised within the concept of territorial status under general international law, the presumption necessarily arises that its meaning was intended to follow the evolution of the law and to correspond with the meaning attached to the expression by the law in force at any given time. ${ }^{20}$

The Court further stated that:

It would then be a little surprising if the meaning of Greece's reservation of disputes relating to its 'territorial status' was not also to evolve in the light of the change in the territorial extent of the Greek State brought about by 'the development of international relations. ${ }^{21}$

The ICJ finally concluded that: "Disputes relating to the territorial status of Greece must be interpreted in accordance with the rules of international law as they exist today, and not as they existed in 1931." In other words, contemporary meaning of the interpreted term should be adopted in contrast with its original meaning almost 50 years ago.

The court's logic is quite straightforward and clear; the core task is to ascertain the particular attribute of the interpreted term, i.e. whether the term is a 
generic term. If it is not a generic, but a specific term, the interpretation needs not to go ahead and the original meaning prevails. Even if confirmed to be a generic term, its meaning is supposed to be evolved into the contemporary meaning. In this case, the original meaning at the time of signing the treaty should be reinterpreted with the related development.

\section{Dissenting Opinion of Judge De Castro}

In this case, Judge De Castro delivered his dissenting opinion regarding the interpretation of contemporary meaning. Judge De Castro emphasized that:

It is a well-established principle that the purpose of interpretation is to ascertain the true will of the parties. The terms used in a declaration of intention must be regarded as the means to be used in order to reach a conclusion as to the intention of the authors of the declaration. When a declaration of intention made a considerable time ago has to be construed, it will always be necessary to verify how the words should be understood at the present time. The meaning of words may change with time. In order to interpret any statement, to ascertain its real meaning, we must first of all concentrate on the meaning which it could have had at the time when it was made. ${ }^{22}$

In addition to this viewpoint, he cited a similar opinion as follows:

The Court has said it "cannot base itself on the purely grammatical interpretation of the text. It must seek the interpretation which is in harmony with a natural and reasonable way of reading the text, having due regard to the intention of the Government of Iran at the time when it accepted the compulsory jurisdiction of the Court." 23

Judge De Castro is believed to attach more importance to the consensus intention of the parties instead of the semantic nature of the terms to be interpreted.

Meanwhile, Judge De Castro enunciated personal insight concerning the relationship between the evolution of law and the meaning of the terms to be interpreted. He held that:

The evolution of law cannot modify the meaning which the words had for the authors of the declaration. The evolution of law can, by establishing new legal 
rules, confer or withdraw rights, and can even change an entire legal régime, but it cannot change the meaning of a declaration: it cannot make the declarant say what he did not wish to say or even what he could not have wished to say. There is even less reason to interpret a unilateral declaration, like Greece's accession to the General Act in 1931, as including a reference to the continental shelf. It would not be right to attribute to Greece a manifestation of will concerning something of which it was unaware and which, for that reason, it could not have intended. $^{24}$

In contrast with the dominant interpretation of other judges of the ICJ, consequently, Judge De Castro placed greater emphasis on the significance of the original meaning of the interpreted terms than the meaning of the terms which were made or even expected by the treaty makers. This dissenting opinion, legally rational to some extent, proves the existence of skepticism about the generic-related semantic analytical mode. Furthermore, this skepticism has not faded away during the further development and adoption of the generic-related semantic analytical mode. ${ }^{25}$ To a certain extent, this fact itself reflects the relative validity of this analytical mode which should be applied on a case-by-case basis.

\section{B. Dispute Regarding Navigational and Related Rights (Costa Rica v. Nica- ragua)}

\section{1. overview}

Costa Rica v. Nicaragua was essentially a dispute over certain sorts of commercial navigational rights to a boundary river delineated by a bilateral Treaty of Limits of 1858. The Treaty posited the San Juan River as the border between the two States; the entire river would be under Nicaraguan sovereignty, while Costa Rica would retain a right of free navigation over the river for the purpose of commerce (comercio). This case focused on the meaning of the term "con objetos de comercio" which was incorporated in that treaty. For Nicaragua, this expression must be translated into English as "with articles of trade." In other words, the 'objetos' in question here are objects in the concrete and material sense of the term. Consequently, the freedom of navigation guaranteed to Costa Rica by Article VI relates only to the transport of goods intended to be sold in a commercial exchange. For Costa Rica, on the contrary, the expression means in English "for the purposes of commerce." The 'objetos' in the original text are therefore said 
to be objects in the abstract sense of ends and purposes. According to Costa Rica, the freedom of navigation given to it by the Treaty must be attributed the broadest possible scope, and in any event encompasses not only the transport of goods, but also the transport of passengers, including tourists. ${ }^{26}$ To interpret the term, the ICJ first stated that it would do so in terms of customary international law on the subject, as reflected in Articles 31 and 32 of the 1969 Vienna Convention on the Law of Treaties. ${ }^{27}$ As to the key term, 'commerce' becomes a point at issue.

Nicaragua argues, even if the phrase is translated as "for the purposes of commerce," the result should the same, because, in 1858, the word 'commerce' necessarily meant trade in goods and did not extend to services, the inclusion of services being a very recent development. ${ }^{28}$ Nicaragua admits that passengers were already being transported on the San Juan in 1858, and even that this was an especially profitable activity. However, it adds that this activity did not fall within the scope of what was commonly called 'commerce' at that time. As for the transport of tourists, there was no such activity in question at that time and in this area. ${ }^{29}$

\section{The inherent interpretative logic}

The ICJ first agreed with Nicaragua to ascertain the meaning a term had when the Treaty was drafted, as doing so can shed light on the parties' common intention. Besides, the Court so proceeded in certain cases requiring it to interpret a term whose meaning had evolved since the conclusion of the treaty at issue, and, in those cases, the Court adhered to the original meaning. ${ }^{30}$

According to the Court, "this does not, however, signify that, where a term's meaning is no longer the same as it was at the date of conclusion, no account should ever be taken of its meaning at the time when the treaty is to be interpreted for purposes of applying it." ${ }^{31}$ Then, the Court put forward two main reasons for adopting contemporary meaning instead of original meaning. One is that the subsequent practice of the parties, within the meaning of Article 31(3)(b) of the Vienna Convention on the Law of Treaties, can result in a departure from the original intent on the basis of a tacit agreement between the parties. The other is that there are situations in which the parties' intent upon the conclusion of the treaty was, or may be presumed to have been, to give the terms used - or some of them - a meaning or content capable of evolving, not one fixed, so as to make al- 
lowance for, among other things, the developments in international law. ${ }^{32}$

Subsequently, the Court refers to an illustration of this reasoning in the judgment of Aegean Sea Continental Shelf handed down on December 18, 1978. Here, the meaning of 'territorial status' was contested. The Court stated:

Once it is established that the expression 'the territorial status of Greece' was used in Greece's instrument of accession [to the General Act of 1928] as a generic term denoting any matters comprised within the concept of territorial status under general international law, the presumption necessarily arises that its meaning was intended to follow the evolution of the law and to correspond with the meaning attached to the expression by the law in force at any given time. This presumption, in the view of the Court, is even more compelling when it is recalled that the 1928 Act was a convention for the pacific settlement of disputes designed to be of the most general kind and of continuing duration, for it hardly seems conceivable that in such a convention terms like 'domestic jurisdiction' and 'territorial status' were intended to have a fixed content regardless of the subsequent evolution of international law. ${ }^{33}$

The Court held that the reasoning in the case is fully transposable for purposes of interpreting the Treaty. It is founded on the idea that, where the parties have used generic terms in a treaty, the parties necessarily have been aware that the meaning of the terms was likely to evolve over time, and where the treaty has been entered into for a very long period or is "of continuing duration," the parties must be presumed, as a general rule, to have intended those terms to have an evolving meaning. ${ }^{34}$ Accordingly, this is so in the case in respect of the term 'comercio' as used in Article VI of the 1858 Treaty. First, this is a generic term, referring to a class of activity. Second, the 1858 Treaty was entered into for an unlimited duration; from the outset it was intended to create a legal régime characterized by its perpetuity. 35

Finally, the Court concluded that the terms by which the extent of Costa Rica's right to free navigation had been defined, including in particular the term 'comercio,' must be understood to have the meaning they bear on each occasion on which the treaty is to be applied, and not necessarily their original meaning. Thus, even assuming that the notion of 'commerce' of the mid-nineteenth century does not have the same meaning of today, it is the present meaning which must be accepted for purposes of applying the Treaty. ${ }^{36}$ 
By comparison, in the adjudication of the second case, the ICJ almost adopted the same interpretative logic as explicated in the first case and also directly cited its core text of the interpretation to confirm the justification of this logic.

\section{Separate Opinion of Judge Skotnikov}

Judge Skotnikov delivered a separate opinion which is against the generic-related analytical mode adopted by the ICJ. In this separate opinion, Judge Skotnikov stresses the significance of the common intention of the parties of the related treaty. He opined as follows:

The Court should have examined the intentions of the Parties at the time of the conclusion of the Treaty... ${ }^{37}, \ldots$, no evidence submitted by the Parties showed that Nicaragua and Costa Rica intended at the time the Treaty was concluded to give an evolving meaning to the word 'commerce'. Accordingly, the Court's presumption should have been that Nicaragua, when concluding the 1858 Treaty, was unlikely to have intended to act against its own interest by granting Costa Rica navigational rights which were not in line with the contemporaneous meaning of the term 'comercio' and which would evolve and expand over time along with the meaning of that term. ${ }^{38}$

Judge Skotnikov also pointed out that:

Neither the generic nature of the term 'commerce' nor the unlimited duration of the Treaty and the perpetuity of the legal régime established by it excludes the possibility that the Parties' intention was to grant Costa Rica navigational rights determined by the content of the notion 'commerce' as it existed when the Treaty was concluded. The Court's solution is based solely on the mechanical application of the jurisprudence which in a particular case favors the evolutive approach (see Aegean Sea Continental Shelf (Greece v. Turkey), Judgment, I.C.J. Reports 1978, p. 3). ${ }^{39}$

It seems that Judge Skotnikov did not agree with adopting the contemporary meaning according to the views above. Nevertheless, like the Court, he proposed to adopt the contemporary meaning but based on different reasons in terms of subsequent practice. Specifically, "the common view of the Parties to that effect can be inferred from the Agreement of Understanding on the Tourist Activity in 
the Border Zone of the San Juan River between the Ministers of Tourism of the two countries, signed on 5 June 1994."40

Although Judge Skotnikov proposes to adopt the contemporary meaning, the analytical mode or the interpretive logic is completely different from the generic-related semantic analysis. By comparison, this separate opinion attaches more importance to the analysis of the substantive elements in the specific case instead of simply invoking the interpretative mode which was adopted in previous similar cases. The existence of this separate opinion, which threw doubt on the mechanical application of the jurisprudence of the evolutive approach, clearly reflects the relative validity of this analytical mode and the fact so that this mode should be applied on a case-by-case basis, either.

\section{Two Additional Cases}

It is noteworthy that there also exists two other similar cases. These are the Rights of Nations of the United States of America in Morocco (France v. U.S.) and Kasikili/Sedudu Island (Botswana/Namibia). In contrast with the two cases above, these cases have distinct characteristics. One is that the contemporary meanings were not adopted; the other is that the generic-related analytical mode was not adopted, either.

In the first case, the Court adopted the original meaning of the term by means of comparing the same term in other treaties. In the second case, the Court adopted the original meaning of the term by reason of the result of the treaty interpretation that neither subsequent agreement existed, nor the related facts and events adduced could be regarded as the subsequent practice in the context of Article 31 of the Vienna Convention on the Law of Treaties.

Here, the generic-related semantic analytical method is a one-step mode. If a term is interpreted to be 'generic,' then the contemporary meaning of the term should be adopted. Conversely, the interpretative method of subsequent practice or agreement is a two-step mode. The first step is to make sure whether there exists subsequent practice/agreement. If existing, then the second step is to explore whether the contemporary meaning resulting from the subsequent practice/agreement should be adopted. If there is no such subsequent practice/agreement, like this case, the original meaning should be adopted.

The existing interpretative approach of subsequent practice/agreement signi- 
fies the possible alternative solution to make adequately rational and economically efficient interpretation concerning whether to adopt contemporary meaning or original meaning, ultimately to avoid automatically adopting contemporary meaning by means of semantic generic-related analysis.

\section{The Two WTO Cases}

\section{A. United States - Import Prohibition of Certain Shrimp and Shrimp Products}

1. The corresponding similarities and dissimilarities

The Appellate Body finally adopted the contemporary meaning of the term in this case. In addition to adopting the contemporary meaning, the legal reasoning of these two cases, Costa Rica v. Nicaragua and US - Shrimp, seems to be the same. As a matter of fact, however, the essential inherent logic is different to some extent.

\section{The similarities}

The Appellate Body report of this case clearly stated that: "The words of Article $\mathrm{XX}(\mathrm{g})$, 'exhaustible natural resources', were actually crafted more than 50 years ago. They must be read in light of contemporary concerns of the community of nations about the protection and conservation of the environment." ${ }^{, 42}$ Furthermore, the Appellate Body clarified that: "from the perspective embodied in the preamble of the WTO Agreement, we note that the generic term 'natural resources' in Article XX $(\mathrm{g})$ is not 'static' in its content or reference but is rather 'by definition, evolutionary." "43 After related analysis, the Appellate Body reached the conclusion that: "The sea turtles here involved constitute "exhaustible natural resources" for purposes of Article XX(g) of the GATT 1994." "44 The Appellate Body illuminated the justification of adopting the contemporary meaning of the term by virtue of the similar terminology, such as 'contemporary concerns,' 'generic term,' 'evolutionary,' etc. ${ }^{45}$

\section{The dissimilarities}

There is one evident difference which is derived from the cited content in the preamble of the WTO Agreement. The Appellate Body states clearly that: 
The words of Article XX (g), 'exhaustible natural resources', were actually crafted more than 50 years ago. They must be read by a treaty interpreter in the light of contemporary concerns of the community of nations about the protection and conservation of the environment. While Article XX was not modified in the Uruguay Round, the preamble attached to the WTO Agreement shows that the signatories to that Agreement were, in 1994, fully aware of the importance and legitimacy of environmental protection as a goal of national and international policy. The preamble of the WTO Agreement -- which informs not only the GATT 1994, but also the other covered agreements--explicitly acknowledges 'the objective of sustainable development. ${ }^{46}$

Besides, the Appellate Body refers to the related text of the preamble:

\section{The Parties to this Agreement,}

Recognizing that their relations in the field of trade and economic endeavour should be conducted with a view to raising standards of living, ensuring full employment and a large and steadily growing volume of real income and effective demand, and expanding the production of and trade in goods and services, while allowing for the optimal use of the world's resources in accordance with the objective of sustainable development, seeking both to protect and preserve the environment and to enhance the means for doing so in a manner consistent with their respective needs and concerns at different levels of economic development...

Then, essentially based on the cited objective of sustainable development codrafted by all the members at that time, the Appellate Body concluded that:

From the perspective embodied in the preamble of the WTO Agreement, we note that the generic term 'natural resources' in Article XX(g) is not 'static' in its content or reference but is rather 'by definition, evolutionary. ${ }^{48}$

\section{The core difference}

In contrast with the corresponding part in the preamble of GATT 1947, one significant difference from the above-cited part in the preamble of the WTO Agreement should be underlined. It was drafted in the corresponding part of the preamble of GATT 1947 which is the prototype of the preamble of the WTO Agreement: 
Recognizing that their relations in the field of trade and economic endeavour should be conducted with a view to raising standards of living, ensuring full employment and a large and steadily growing volume of real income and effective demand, developing the full use of the resources of the world and expanding the production and exchange of goods...

Looking at the text, it is easy to perceive the difference regarding resources. The GATT 1947 draft emphasized the objective of "full use of the resources of the world. ${ }^{, 50}$ Obviously, the inherent logic is straightforward in terms of full use of the resources without simultaneously considering other related perspectives. On the contrary, at the time of drafting the WTO Agreement, emphasis varied from "full use of the resources of the world" "51 to "optimal use of the world's resources in accordance with the objective of sustainable development." ${ }^{, 52}$ Accordingly, the balance between the "use of resources" and the "objective of sustainable development" is one of the core ideas dominating WTO-related issues. Also, this is the reason why the Appellate Body cited the original text in the preamble of the WTO Agreement to substantiate and justify the adoption of the contemporary meaning which is in line with such balance consisting in the WTO legal system.

Consequently, the preamble-related element regarding the principle of appropriate balance between trade and protection for environment in this case is the key to justifying for adopting the contemporary meaning. This is the core difference from the ICJ case above.

\section{B. China - Measures Affecting Trading Rights and Distribution Services for Certain Publications and Audiovisual Entertainment Products (WT/ DS363)}

\section{Brief introduction}

This is the most recent one among the four cases. As summarized above, although China refuted the foregoing specific conclusion of the panel in the appeal, the Appellate Body finally upheld it by means of detailed treaty interpretation.

The treaty interpretation in WT/DS363 involves a certain principle in the preamble of the GATS and the interpretative logic should also be the same as that in US - Shrimp. Briefly, the first step is to make sure whether there exists contemporary meaning of the term to be interpreted, which is different from the original 
meaning of that term at the time of the legally effective date of the treaty, while the second step is to scrutinize the related principles in a certain treaty or treaties, aiming to decide whether the related principle should reinforce the adoption of the contemporary meaning or block such adoption. Thus, it is very clear that the Appellate Body almost utilized the same legal reasoning in this appeal to justify the adoptability of the contemporary meaning of the key terms.

The Appellate body considered that the terms used in China's GATS Schedule ('sound recording' and 'distribution') were sufficiently generic so that they would apply and change them over time. In this respect, GATS Schedules, like the GATS itself and all WTO agreements, constituted multilateral treaties effectively continuing with the new WTO Members. ${ }^{53}$ In the footnote of this paragraph, especially, the Appellate Body referred to its Reports in both US - Shrimp (WTO) and Costa Rica v. Nicaragua (ICJ), in order to justify the adoption of the contemporary meaning of the terms. But is it also adequately justified to adopt the contemporary meaning in this case? A thorough comparison between the related details is necessary.

\section{The analytical logic in the appeal}

On appeal, China claimed that the Panel interpreted the entry "sound recording distribution services" according to the contemporary meaning of the words it contains, but that the principle of 'progressive liberalization' did not allow for the expansion of the scope of the commitments of a WTO Member by interpreting the terms used in the Schedule based on the meaning of those terms at the time of interpretation. ${ }^{54}$ Compared with the two-step analytical approach above, the argument in the claim is legally logical indeed. In contrast, the positions of the Appellate Body is controversial as follows. First, the Appellate Body stated that:

We do not disagree with the Panel that nothing in the GATS preamble appears to contradict an interpretation of 'Sound recording distribution services' as extending to electronic distribution of sound recordings. At the same time, we observe that none of the objectives listed in the GATS preamble provides specific guidance as to the correct interpretation to be given to China's GATS Schedule entry 'Sound recording distribution services. ${ }^{55}$

Put it in another way, no principle in the GATS preamble can legally affect the 
treaty interpretation on this particular claim.

Second, the Appellate Body specifically explained the reason why the principle of 'progressive liberalization' has no effect on the interpretation as follows:

The principle of progressive liberalization is reflected in the structure of the GATS, which contemplates that WTO Members undertake specific commitments through successive rounds of multilateral negotiations with a view to liberalizing their services markets incrementally, rather than immediately and completely at the time of the acceptance of the GATS. The scheduling of specific commitments by service sectors and modes of supply represents another manifestation of progressive liberalization. In making specific commitments, Members are not required to liberalize fully the chosen sector, but may limit the coverage to particular subsectors and modes of supply and maintain limitations, conditions, or qualifications on market access and national treatment, provided that they are inscribed in their Schedules. We do not consider, however, that the principle of progressive liberalization lends support to an interpretation that would constrain the scope and coverage of specific commitments that have already been undertaken by Members and by which they are bound. ${ }^{56}$

From the key articulation of "have already been undertaken by Members" in the above paragraph, the Appellate Body has indirectly adjudicated that the contemporary meaning overrode the original meaning in this case because related commitment of electronic distribution of sound recordings by foreign-invested enterprises had been 'already undertaken' by China. Finally, the Appellate Body mentioned that:

We consider that the terms used in China's GATS Schedule ('sound recording' and 'distribution') are sufficiently generic that what they apply to may change over time. ${ }^{57}$

This articulation is evidently intended to show that the terms have contemporary meaning, which is not exactly same as the original meaning, at the time when they are interpreted in this case.

\section{The principle of progressive liberalization in WT/DS363}


In summary, the analysis of the contemporary meaning of the key term is not controversial in this case. Indeed, from China's accession to the WTO to the initiation of this case, technology had rapidly developed, especially in internet-based technologies. These advances have incrementally expanded the scope of trade cross-border services, such as the internet-based service of electronic distribution of sound recordings. Until now, "the rapid expansion of electronic commerce (ecommerce) is impacting economic activities both at the national and international levels. ${ }^{~} 58$ Nobody could deny that the electronic distribution of sound recordings, which is a sort of e-commerce, is currently getting more important in the form of distribution service. Does the principle of 'progressive liberalization' in the preamble of the GATS, however, definitely exert no legal effect on the treaty interpretation concerning the contemporary meaning above? The Appellate Body illuminated that:

The principle of progressive liberalization is reflected in the structure of the GATS, which contemplates that WTO Members undertake specific commitments through successive rounds of multilateral negotiations with a view to liberalizing their services markets incrementally, rather than immediately and completely at the time of the acceptance of the GATS. ${ }^{59}$

The statement is essentially coherent with the corresponding expression in US Gambling. In this case, the Panel noted that:

Progressive liberalization entails including more sectors in Members' schedules and reduction or elimination of limitations, terms, conditions and qualifications on market access and national treatment through successive rounds of negotiations. $^{60}$

This principle exactly reflects that the GATS is just a general legal framework and further liberalization of specific service should take the form of undertaking specific commitments by members through successive rounds of multilateral negotiations. ${ }^{61}$ In fact, however, the corresponding negotiations in the service arena have not been proceeding smoothly. The main cause is the conflict of trade interests between the developed and the developing/least developed country ("LDC") members. On the whole, the developed members certainly seek higher level of 
liberalization in trade in service by efficient rounds of further negotiations. ${ }^{62}$ On the contrary, the developing/LDC members generally persist in conducting the negotiations on the basis of the principle of progressive liberalization to achieve the balance of rights and obligations and to promote the level of liberalization in trade in service progressively. ${ }^{63}$ Besides, the "Guidelines and Procedures for the Negotiations on Trade in Services" approved by the Council for Trade in Services, in Special Session in March 2001 emphasized the objective of progressive liberalization and the appropriate flexibility for developing countries, with special priority to be given to the least-developed countries. ${ }^{64}$

Consequently, the principle of progressive liberalization in the GATS preamble is especially crucial to the developing/LDC members because this principle can be deemed as the crucial protection against unjustified unilateral argument by certain developed members for a high level of liberalization of certain services without further negotiation.

\section{A more justified treaty interpretation}

Although the Appellate Body adequately paid attention to the similarities between WT/DS363 and the US - Shrimp and Costa Rica v. Nicaragua cases with regard to the contemporary meaning of a certain term to be interpreted, it would not fully consider the particularities of WT/DS363 such as the existence of the principle of progressive liberalization in the GATS preamble.

When making specific commitments for the accession to the WTO, internetbased commercial activities did not exist in China, or at least were quite rare. This is the key to understanding why the service of internet-based electronic distribution of sound recordings was not explicitly listed in China's GATS Schedule. If the contemporary meaning in this case were absolutely adoptable irrespective of any other aspect, the principle of progressive liberalization in the GATS preamble would become meaningless and redundant to some extent. In practice, however, the principle of progressive liberalization is legally effective to all the members. Thus, the neglect of this principle leads to an unjust adjudication on this point. In other words, the adjudication equals to the deprivation of China's rights of further negotiation concerning this specific form of distribution service. China can obtain new rights as the tradeoff for undertaking new obligations through new rounds of negotiation to achieve progressive liberalization. 
Like the tradeoff suggested as a link, e.g., "a link could lend credibility to both liberalization and assistance programs. In their service schedules, developing countries would commit to phasing-in liberalization over a certain period of time, and developed countries would commit to providing the requisite technical assistance." ${ }^{65}$ Thus, the deprivation of China's rights of further negotiation caused by the treaty interpretation means that China can only undertake new obligations, but cannot fairly obtain new rights.

To sum up, the following are more justified treaty interpretations, with the same two-step analytical logic as adopted in US - Shrimp. They would be more de jure reasonable.

First, the contemporary meaning of a term should be interpreted by the Appellate Body as adopted in US - Shrimp and Costa Rica v. Nicaragua, although this semantic generic-related analytical mode is not perfect.

Second, once the contemporary meaning of the term is decided to exist, the rules or principles in the preamble of related treaty should be carefully considered, just as the Appellate Body did in US - Shrimp. In US - Shrimp, the Appellate Body affirmed the contemporary meaning after carefully reviewing the related text of the WTO Agreement; it finally adopted the contemporary meaning of the interpreted term. ${ }^{66}$ The Appellate Body in this case, however, negated the adoption of the contemporary meaning of the interpreted term based on the principle of progressive liberalization in the GATS preamble according to the analysis above. Although the Appellate Body in this case de facto enjoyed certain discretion for interpreting treaty, consequently, the interpretation and the corresponding adjudication did not go beyond the consensus embodied in the key principles of the related treaty, especially those that were drafted to safeguard the trade interests of the developing/LDC members. Such a two-step analysis should be conducive to promote the consistency and coherency in the adjudication of the cases under the same category. Besides, this interpretation can be applied to the new commitments concerning e-commerce within the framework of the GATS. Mattoo, Stern, and Zanini stated that:

If a WTO member has made a commitment in a particular sector to provide national treatment, then all discriminatory taxes are already prohibited and so the ban adds nothing. Conversely, if a member has not made a national treatment commitment, it remains free to impose discriminatory internal taxes other than 
customs duties, so again the ban has little value. Based on this analysis, it seems reasonable to argue that the most effective route to ensure liberalization of electronic commerce is to expand the GATS specific commitments. ${ }^{67}$

Evidently, with respect to the liberalization of electronic commerce which was not explicitly committed by a member, the expansion of the GATS specific commitments in terms of conducting further negotiations should be the effective approach to promote the liberalization of electronic commerce.

Thus, it is reasonable and fair to ensure liberalization of electronic commerce, like the disputed electronic distribution of sound recordings in WT/DS363, through further negotiations.

\section{Further Reflections on the ReLATEd DifFERENCES BETWEEN THE ICJ AND THE WTO}

As mentioned above, the ICJ and WTO cases contain differences in principle. Especially from the economic point of view, e.g., the principle of progressive liberalization may be deemed as the "ultimate interest separator," which accordingly can trump the generic-related analysis. An Appellate Report of the WTO elucidated:

\footnotetext{
The WTO Agreement is a treaty - the international equivalent of a contract. It is self-evident that in an exercise of their sovereignty, and in pursuit of their own respective national interests, the Members of the WTO have made a bargain. In exchange for the benefits they expect to derive as Members of the WTO, they have agreed to exercise their sovereignty according to the commitments they have made in the WTO Agreement. ${ }^{68}$
}

Thus, this straightforward illumination clearly discloses the very core of the essential attributes of the institutional framework of the WTO system and the WTO Agreement. In general, the multilateral trading system under the WTO needs a kind of agreement focusing more on trade/economic interest than that of the ICJ which is rather politically attributed. Such characteristics of the WTO should be especially considered while interpreting the treaties in accordance with the Vi- 
enna Convention on the Law of Treaties. ${ }^{69}$

In China - Measures Affecting Trading Rights, e.g., the principle of progressive liberalization in the GATS preamble was essentially justified from the economic point of view. Thus, according to the perspective of existing interestbalance, the service of electronic distribution of sound recordings, which was burgeoning in China at that time but not directly included in the China's GATS Schedule, should not be interpreted to be within the scope of China's GATS Schedule mainly because the related terms were interpreted as 'generic.' Moreover, there is still no such authoritative and universally acknowledged standard on how to confirm whether a term is 'generic' or "not under certain circumstances." This is perhaps the main reason why some Chinese scholars publicly criticized the related reasoning in the Appellate Body report. ${ }^{70}$

If some economic analysis on law can be added to the generic-related legal interpretation, the interpretation could possibly be more satisfactory. The ultimate aim of the WTO dispute settlement system is not to continuously develop advanced techniques of interpretation, but to correctly and fairly clarify the point of interest balance concerning specific dispute.

Briefly, in spite of some similarities between the ICJ and WTO cases, the principle-related aspect of the WTO cases should be noted in the subsequent cases.

\section{Conclusion}

By virtue of detailed comparison between the four cases in the ICJ and two cases in the WTO, some similarities and dissimilarities can be ascertained. Especially, the significant dissimilarities concerning certain principles should be emphasized. No matter the related principle enshrined in certain agreement focuses on the economic or environmental aspect, etc., particularly in the context of WTO dispute settlement, the contemporary meaning could only be adoptable after adequately justifying treaty interpretation by means of the two-step semantic generic-related interpretative approach. Without the second step of principle-related analysis, problems may arise especially from the economic perspective in terms of inappropriate interest-balance. 


\section{REFERENCES}

1. Appellate Body Report, United States - Import Prohibition of Certain Shrimp and Shrimp Products (U.S. v. India; Malay.; Pak.; \& Thai.), WT/DS58/AB/RW (Oct. 22, 1998), available at http://www.wto.org/english/tratop_e/dispu_e/cases_e/ds58_e.htm (last visited on Feb. 21, 2015).

2. Only a few English articles discusses some details regarding the 'contemporary meaning' of the interpreted term in either the WTO dispute settlement or the ICJ. See Pengcheng Gao, Rethinking The Relationship between the WTO And International Human Rights, 8 Rich. J. Global L. \& Bus. 397 (2009); M. Footer, The (Re) Turn To 'Soft Law' In Reconciling The Antinomies In WTO Law, 11 MelB. J. Int'L L. 241 (2010); C. Lumina, Free Trade or Just Trade? The World Trade Organisation, Human Rights and Development (Part 1), 12 L., Democracy \& Dev. 20 (2008); E. Criddle \& E. Fox-Decent, New Voices: Rethinking the Sources of International Law, 103 Am. Soc'y Int'L L. Ann. Meeting Proc. 71 (2009); J. Cogan, Current Developments: The 2009 Judicial Activity of The International Court of Justice, 104 Ам. J. Int'L L. 605 (2010); J. Arato, Subsequent Practice and Evolutive Interpretation: Techniques of Treaty Interpretation over Time and Their Diverse Consequences, 9 L. \& Prac. InT'L Cts. \& TRib. 443 (2010).

3. E. Cannizzaro, The Law of Treaties beyond the Vienna Convention 123 (2011).

4. For all the issued judgments, advisory opinions and orders in the ICJ, see the official website of the ICJ, available at http://www.icj-cij.org/docket/index.php?p1=3\&p2=2. For the Panel Reports and Appellate Body reports, see the official website of the WTO, available at http://www.wto.org/english/tratop_e/dispu_e/dispu_e.htm (last visited on Feb. 16, 2015); World Trade Law.Net, available at http://www.worldtradelaw.net/dsc/dscpage.htm (all last visited on Feb. 16, 2015).

5. Aegean Sea Continental Shelf (Greece v. Turk.), Judgment, 1978 I.C.J. $\uparrow 6$ (Dec. 19).

6. Dispute regarding Navigational and Related Rights (Costa Rica v. Nicar.), Judgment, 2009 I.C.J. 213 (July 13).

7. Rights of nations of the United States of America in Morocco (Fr. v. U.S.), Judgment, 1952 I.C.J. 176 (Aug. 27).

8. Kasikili/Sedudu Island (Bots. v. Namib.), Judgment, 1999 I.C.J. 1045 (Dec. 13).

9. Legal Consequences for States of the Continued Presence of South Africa in Namibia (South West Africa) notwithstanding Security Council Resolution 276, Advisory Opinion, 1971 I.C.J. 16 (June 21).

10. Id. at 31 .

11. Panel Report, China - Measures Affecting Trading Rights and Distribution Services for Certain Publications and Audiovisual Entertainment Products (China v. U.S.), Request for Consultations, WT/DS363/1 (Apr. 16, 2007), available at https://docs.wto.org/dol2fe/ Pages/FE_Search/FE_S_S006.aspx?Query=(@Symbol=\%20wt/ds363/r*\%20not\%20rw*) 
$\&$ Language $=$ ENGLISH $\&$ Context $=$ FomerScriptedSearch\&languageUIChanged $=$ true $\#$ (last visited on Feb. 21, 2015)

12. Appellate Body Report, China - Measures Affecting Trading Rights and Distribution Services for Certain Publications and Audiovisual Entertainment Products (China v. U.S.), WT/DS363/AB/R, 161 (Dec. 21, 2009), available at https://docs.wto.org/dol2fe/Pages/FE_ Search/FE_S_S006.aspx?Query=(@Symbol=\%20wt/ds363/ab/r*\%20not\%20rw*)\&Langu age=ENGLISH\&Context=FomerScriptedSearch\&languageUIChanged=true\# (last visited on Feb. 20, 2015).

13. As to this case and other related issues, see Work of the Court in 1978-1979, 33 I.C.J. Y.B. 118 (1978-1979); A. Georgopoulos, Delimitation of the Continental Shelf in the Aegean Sea, 12 Fordham Int'L L. J. 90 (1989); J. Vassalotti, Rough Seas: The Greek-Turkish Aegean Sea Dispute and Ideas for Resolution, 33 Loy. L.A. Int'L \& Comp. L. Rev. 387 (2011).

14. Aegean Sea Continental Shelf (Greece v. Turk.), Judgment, 1978 I.C.J. 6 - 12 (Dec. 19), available at $\mathrm{http}: / \mathrm{www}$.icj-cij.org/docket/index.php?p1 $=3 \& \mathrm{p} 2=3 \& \mathrm{k}=81 \&$ case $=62 \&$ code $=$ gt\&p3=4 (last visited on Feb. 20, 2014).

15. Id. at $27 \& 31-34$.

16. Chapters III \& IV of this paper.

17. Supra note $14, \uparrow 64$.

18. Id. $ๆ 74$.

19. Id. 175 . [Emphasis added]

20. $I d .977$.

21. Id. $ๆ 78$.

22. Aegean Sea Continental Shelf (Greece v. Turk.), 1978, I.C.J. at 64, 4 (n. 1) (Dec. 19) (dissenting opinion of Judge de Castro), available at http://www.icj-cij.org/docket/index. $\mathrm{php} ? \mathrm{p} 1=3 \& \mathrm{p} 2=3 \& \mathrm{k}=81 \&$ case $=62 \&$ code $=\mathrm{gt} \& \mathrm{p} 3=4$ (last visited on Feb. 20, 2015).

23. Supra note 7, 104.

24. Supra note 22 , at $₫ 12$.

25. Infra note 62.

26. Supra note 6 , at 945 .

27. $I d .947$.

28. $I d . ๆ 58$.

29. $I d . \Upsilon 58$.

30. $I d . \Upsilon 63$.

31. Id. ๆ 64.

32. Id.

33. Supra note 5 , 977.

34. Dispute regarding Navigational and Related Rights (Costa Rica v. Nicar.), Judgment, 2009 I.C.J. \ 66 (July 13). 
35. Id. $\uparrow 67$.

36. Id. $\uparrow 70$.

37. Dispute regarding Navigational and Related Rights (Costa Rica v. Nicar.), 2009 I.C.J. $q 4$ (July 13) (separate opinion of Judge Skotnikov)

38. Id. $\llbracket 5$.

39. Id. ๆ 6.

40. Id. $ๆ 9$.

41. Id. $ๆ 79$.

42. Supra note 1 , II 129.

43. Id. $\uparrow 130$.

44. Id. $\uparrow 134$.

45. Supra note 42.

46. Id.

47. GATT 1994: General Agreement on Tariffs and Trade 1994, Apr. 15, 1994, 1867 U.N.T.S. 187, reprinted in 33 I.L.M. 1153, pmbl. (1994). Id.

48. Supra note 43.

49. General Agreement on Tariffs and Trade (1947), 55 U.N.T.S. 194, pmbl., available at http://www.wto.org/english/docs_e/legal_e/gatt47_01_e.htm (last visited on Feb. 20, 2015).

50. Id.

51. Supra note 49.

52. Supra note 47.

53. Supra note 12 , at $\mathbb{I} 396$.

54. Id. $\ 173$

55. Id. 9393.

56. Id. 1394.

57. Id. $₫ 396$.

58. A. Mattoo, R. Stern, \& G. Zanini, A Handbook of International Trade in Services 460 (2007).

59. Supra note 56.

60. Panel Report, United States - Measures Affecting the Cross-Border Supply of Gambling and Betting Services (U.S. v. Ant. \& Barb.), WT/DS285/R, \6.313 (Nov. 10, 2004), available at https://docs.wto.org/dol2fe/Pages/FE_Search/FE_S_S006.aspx?Query=(@ Symbol $=\% 20 \mathrm{wt} / \mathrm{ds} 285 / \mathrm{r} * \% 20$ not $\% 20 \mathrm{rw}^{*}$ )\&Language=ENGLISH\&Context=FomerScript edSearch\&languageUIChanged=true\# (last visited on Feb. 21, 2015).

61. E.g., the Panel of US - Gambling noted that: "Progressive liberalization entails including more sectors in Members' schedules and reduction or elimination of limitations, terms, conditions and qualifications on market access and national treatment through successive rounds of negotiations." Id. 
62. There exist several similar viewpoints. E.g., it is stated that "the move to consider rules for trade in services originated with the United States, which had a large services trade surplus. Many developing countries were opposed to negotiating on services." See J. TRACHTMAn \& C. Thomas, Developing Countries in the WTO Legal System 439 (2009).

63. Chinas explicitly maintained in the appeal that: "The principle of progressive liberalization does not allow the scope of the commitments of a WTO Member to be extended based on 'temporal variations in language.” See China's appellant's submission, I 173, recited from Appellate Body Report, China - Measures Affecting Trading Rights and Distribution Services for Certain Publications and Audiovisual Entertainment Products (U.S. v. China), WT/DS 363/AB/R, $₫ 47$ (n. 97) (Dec. 21, 2009).

64. WTO, Negotiating mandates, available at http://www.wto.org/english/tratop_e/serv_e/ nego_mandates_e.htm (last visited on Feb. 20, 2015).

65. Supra note 58, at 80.

66. Supra note 1 , at 129.

67. Supra note 58 , at 475 .

68. Appellate Body Report, Japan - Taxes on Alcoholic Beverages (Japan v. European Communities), WT/DS8/AB/R, $\uparrow 15$ (Oct. 4, 1996).

69. Vienna Convention on the Law of Treaties, 1155 U.N.T.S. 331, arts. 31-32.

70. See, e.g., Lingliang Zeng, The new trend of treaty interpretation reflected in the Appellate Body report of WT/DS363, in Dispute Settlement of WTO - The Year of China (2009) 164 -75 (Naigen Zhang ed. 2010). 